helped me to publish it " were rendering no service to Nigerian historical scholarship or to their reputation". Mr. Jones would need to present better credentials for his claim to be the sole judge of standards, services, and reputations in Nigerian historiography.'

Professor Jan Vansina (Department of History, University of Wisconsin) writes:

'Concluding his rather derogatory review of J. Alagoa's The Small Brave City-State: a History of Nembe-Brass in the Niger Delta, Mr. G. I. Jones states that " those responsible for directing his [Alagoa's] research should have realized that by supporting publication of his material in this unprepared form they were rendering no service to Nigerian historical scholarship or to their reputation ". As one of the persons concerned, I must state that I welcomed publication of the manuscript because $(a)$ it is based on field-work and a long knowledge of the area, and (b) it is a modest contribution to local history-and this book is just that. These local histories are the very foundations of our historical knowledge and they must be encouraged and published.

"There is nothing " unprepared" about this and the reviewer errs when he has it that the author is now engaged in field-work in that area. Dr. Alagoa did field-work in $1963-4$ to collect materials for his Ph.D. on "The Settlement of the Niger Delta ". The only overlap with this study is pp. 34-50: "Legends of origin." Of course the monograph could have been more perfect-could not all monographs? - but then we also realize that too many worthy manuscripts have been buried because of an appeal to so-called "standards".

'Petty reviews such as this one set back the cause of scholarship rather than promote it. For they try to penalize the historian-professional or amateur-who is bold enough to gather basic data in his field. In fact such reviews make one only wonder what moves the display of such harshness.'

Mr. G. I. Jones replies:

'I am sorry to have to hurt people's feelings but I stick to my guns. I don't think that Dr. Alagoa has really answered or understood my critcisms. I am not concerned with "staking out claims to territory" but with standards of Nigerian historical scholarship. I fully endorse Professor Vansina's assessment of this book. It is, as he says, 'a modest contribution to local history.'

\title{
East Africa and the Orient: Historical Problems of the Pre-Colonial Era
}

A CONFERENCE on this subject will be held from $s$ to 9 April 1967 at the British Institute of History and Archaeology in East Africa, Nairobi, under the sponsorship of the Harvard University Center for International Affairs (Convenor, Robert I. Rotberg), and the British Institute (Convenor, H. Neville Chittick), financed by the Ford Foundation. The programme will include sessions on: the maritime civilizations of Asia; the dating and significance of the Periplus of the Erythraean Sea; the influence of Indonesia: hypotheses and data; the peopling of the coast; material evidence of cultural connexions between the Orient and Africa; the interior of Africa and the Coast. It is expected that participant speakers will include about thirty scholars from institutions in East Africa, Madagascar, Europe, and U.S.A., and we hope to include a further note on the work of the conference in a later number of $A$ frica.

(See also p. 85). 